\title{
Modelling the Interactive Influence of Intellectual Capital Indicators
}

\author{
Henry Anderson Junior and Jan Stejskal \\ University of Pardubice, Czech Republic \\ Henry.anderson@upce.cz \\ Jan.stejskal@upce.cz \\ DOI:10.34190/KM.19.203
}

\begin{abstract}
Knowledge generation, in contemporary times, has dictated the economic strength and national and regional competitive advantage. The advent of the open innovation model has driven firms to collaborate and engage in external interactions to incite their innovation spark to become even more competitive globally and nationally. There have been a wealth of success in creating intellectual capital in the European Union. In line with that, subsequent funding have been provided for small and medium sized firms (SMEs) with the view of assisting them to individually or cooperatively generate intellectual capital. However, even as human resources, cooperation and other environmental factors have been acclaimed to influence regional intellectual capital capacity, we question whether these factors offer an interactively significant influence on themselves in creating intellectual capital. This will enable identification of catalytic indicators to expertly position regional activities that generate regional competitive advantage. Using the Structural equation modelling (SEM) and data from European Innovation Survey (2018), research aims to test the interactive influence of the selected indicators of intellectual capital and their significance in generation intellectual capital represented by patents, trademarks and design applications. The results revealed that whilst research system attractiveness and firm-to-firm or academia linkages were very significant in generating intellectual capital, human capital were not significant in generating intellectual capital contrary to mass of literature. Attractiveness of research systems were strongly significant in affecting the human resource structure and innovation friendliness of member states and generation of intellectual capital. Private, public and venture capital were found to have been strongly influenced by labour structure and friendliness of a geography whilst it also strongly affected the cooperation tendencies of firms and academia. Policies that aligned regional strengths to these findings were further recommended.
\end{abstract}

Keywords: intellectual capital, human capital, public and private funds, cooperation, innovation

\section{Introduction}

In recent times, open Innovation (OI) as a newly-adopted concept and strategy for innovation has been the hailed as the ideal model for innovation in recent years. As an advancement beyond the black box innovation model, the linear and the systemic model of innovation, open innovation has moved firms to exist beyond a selfcentred innovation mentality to a more integrative innovation-oriented structure. Chesbrough (2003a) coined this term and referred to it as "combining internal and external ideas as well as internal and external paths to market to advance the development of new technologies". This model admonishes firms to endorse and actively engage in the knowledge sharing, interaction and cooperate with external entities without fear of imitation but rather with the objective of learning, acquisition of knowledge, being opened to new technological processes and consequently improving and expediting innovation processes. In a quest to boost industrial innovation efforts, a range of research has been conducted by various authors (Dahlander \& Gann, 2010; Chesbrough \& Bogers, 2014; West \& Bogers, 2014) which has entrenched the popularity in adoption of this model for innovation. Clubs and associations have been created to provide a valuable platform for industrial managers to share experiences and practices that may have been crucial in spurring the wider adoption of the term by other firms. These industrial clubs have been supported by academics, helping to promote dialog and debate between open innovation scholars and practitioners. Alongside these academic and practitioner communities, the concept has been taken up by all levels of governments, whether local, regional, national or supra-national West, Salter, Vanhaverbeke, Chesbrough 2014). Overtime, open innovation has come to be redefined in newer contexts to capture the changes in the views of firms in this engagement. Chesbrough and Bogers (2006) now interpret open innovation as "a distributed innovation process based on purposively managed knowledge flows across organizational boundaries, using pecuniary and non-pecuniary mechanisms in line with the organization's business mode".

Small companies are believed to gain more from open innovation as both their resources and market reach are limited and their innovation efforts already have an external focus making them more prepared for a more open innovation interactions (Lee, Park, Yoon and Park, 2010). However, process was feared to be defied by large incorporations owing to their financial prowess and ability to engage multiple personnel with diverse background. 


\section{Henry Anderson Junior and Jan Stejskal}

Cooperation in the European Union is valued as a salient feature that assists in accelerating and reaping the results of innovation creation and even knowledge dissemination (European Commission 2014). Community Innovation Survey (2014) assesses the innovativeness of firms by verifying open innovative efforts of firms (Cricelli, Greco and Grimaldo 2015). Public and private funding to most firms also have begun to endorse the open innovation efforts of SMEs such that funds can be specifically set aside for such innovative orientations.

Research of Cricelli, Greco and Grimaldo (2015) showed that the portion of firms adopting the OI concept has risen, both in terms of inbound and coupled activities. They also revealed that even as firms have intensified the use of the inbound $\mathrm{Ol}$ mode, the use of collaborations had been rarely used. This effectively understates the interactive skill, knowledge extraction and sharing capacities of organisations' inherent human capital in creating generating intellectual capital. Rahman and Ramos (2013) also researched on the limitation of Ol and found that high wage level is creating scarcity of skilled manpower effectively creating a dearth of skilled resources and also inhibiting the firm's ability to employ more diverse persons. There is also a high cost of innovation including an insufficiency in knowledge about Ol strategies. Having known the funding efforts exerted by public and private entities for open innovation scheme and the limitations firms face in their efforts to openly innovate, we aim to assess the interactive influence of selected indicators of intellectual capital on themselves and their significance in the generation intellectual capital represented by patents, trademarks and design applications. In the effort to protect and generate further intellectual capital, within the European Union, this paper will be of such essence that it will reveal the sub variables that not only affects intellectual capital but also shows the degree to which such indicators respond to each other in a catalytic and synergistic effort to enable policy makers carefully position resources to reap the best results from structural and social variables for innovation. This could mitigate the pressure of funding and further funding for innovation activities especially newly introduced funding schemes of the European Union such as the Horizon 2020.

\section{Literature review}

As shown in figure 1, the study tests the model that indicators of intellectual capital have a systemic effect on intellectual capital such that they interact to influence themselves to effectively create both synergetic and individual effects on patents, trademarks and design applications. This model hinges on theoretical propositions of Lundvall (2010), Kwiek (2015), Audretsch and Feldman (2004) who found that human capital of organisations and public and private expenditure as relevant inputs of intellectual capital. Furthermore, there is a debatable use of indicators to measure intellectual capital.

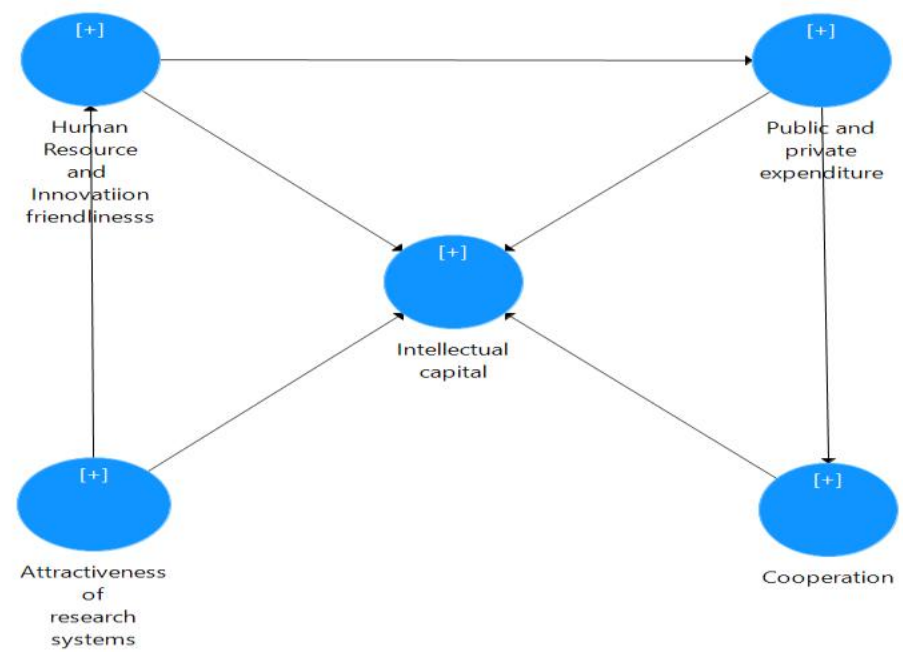

Figure 1: SEM Model structure of variables analysed

The definition of intellectual capital introduced by Bontis (2004) is the one most frequently quoted by scientists in research in that field: "The intellectual capital of a nation includes the hidden values of individuals, enterprises, institutions, communities and regions that are the current and potential sources for wealth creation". According to Jurczak (2008), Luthy (1998) and Bukowitz \& Williams (2000), measuring intellectual capital can be one of the four methods: Direct Intellectual capital methods (DICM), Market Capitalisation Methods (MCM), Return On Assets Methods (ROA) and Scoreboard Methods (SC). However, as used by Bontis (1996), we opted for the citation based measure of DICM which uses the valuation of the number and cost of patents. For comprehensiveness and diversity, we also incorporated design application and trademarks also provided by the 


\section{Henry Anderson Junior and Jan Stejskal}

European Innovation Scoreboard (EIS). It is worth to note that even though intellectual property generally may consist of patents, copyrights, licensing and trademarks, the usage of Citation-weighted patents- enables a measure intellectual capital resources from the bottom up and can therefore be faster and more accurate than ROA and MCM measures with respect to resources. Since they do not need to be measured in financial terms, they are very useful for not-for-profit organizations, business units, government agencies, and for environmental and social purposes.

\subsection{Research attractiveness, human resource and intellectual capital}

In recent times, intellectual capital has been highly revered as a very significant source if not a measure of economic performance (Malhotra 2000). Traditionally, most countries had focused on the impact of land, labour, capital and entrepreneurship as factors determining the economic output, i.e. Gross domestic product (GDP). In this era of knowledge economy, large multinationals corporations such as Facebook and Microsoft strongly pride their marginal returns on additional knowledge and interaction created. Research attractiveness have been lauded as a catalyst for expediting technological innovation and a crucial facilitator of the creation of a stronger knowledge network. Research has shown that firms need to protect their knowledge when they engage in formal external collaboration (Cassiman and Veugelers, 2002, Heiman and Nickerson, 2004) as this is a means that firms accesses skills and knowledge unavailable within the boundaries of their organizations. Kwiek (2015) researched on 11 European Union member states to reveal the impact research collaboration on productivity of research. He found that European Union member states research productivity in Europe had a direct correlation with international research collaboration. Lee and Bozeman (2005) also researched to find out the impact of research collaboration on scientific productivity. They found contrasting results that revealed that when scientific productivity was measured by 'normal count' (a scientist's total number of publications), collaboration was a strong predictor of publishing productivity. When publishing productivity was measured by 'fractional count' (dividing credit by the number of co-authors), collaboration and publishing productivity were found not to be significantly related when they controlled for moderating variables. However, in a practical sense, not all persons are moved by attractive structures as most are rather attracted by sumptuous compensation packages. Due to the development of innovation beyond the systemic model to even the open innovation structure, it is believed that an attractive research structure could be a bait for attracting highly qualified personnel and also reducing attrition rate of currently existing research persons inadvertently determining the quality and diversity of human resources research personnel. Hence, we hypothesise that "attractiveness of research systems has an impact on human capital and innovation friendliness"- $\mathrm{H} 1$.

\subsection{Human capital, firm funding and intellectual capital}

Existing research on human capital and performance has unanimously demonstrated that effective human capital management is a significant contributor to organizational performance (Macduffie, 1995; Delaney \& Huselid, 1996; Combs, Liu, Hall, \& Ketchen, 2006; Jiang, Lepak, Hu, \& Baer, 2012;) irrespective of whether it is assessed from the universalistic perspective (the so-called best practice approach) or the configurational perspective (the application of bundles of interrelated HRM practices) (Boxall \& Purcell, 2003; Delery \& Doty, 1996). There is the assumption that organization's capacity to innovate dwells in its employees' capacities, their intrinsic and extrinsic motivation owing to the undeniable need of human capital in the development and implementation of innovations (Jiménez-Jiménez \& Sanz-Valle, 2008).

According to Seeck and Diehl (2016), this assumption above reflect two dimensions of the effect of human capital on innovation- the best practice approach which asserts that firms will improve their innovative performance if they implement certain best practices- and the bundled approach which concerns supporting employee commitment to affect firm innovative efforts. In this vein, Zhou, Hong and Liu (2013) assessed 179 organizations in China to examine the interaction effects of two HRM systems on affecting firm innovation and performance. They found that both systems assessed, the commitment-oriented system and the collaboration-oriented system. Using structural equations modelling, Jimenez and Valle (2008) assessed one hundred and seventy-three (173) Spanish manufacturing firms to analyse human capital effect on innovation. The findings showed that innovation contributes positively to business performance and that human resource management enhances firm's patents generated for innovation. Liu (2013) also researched on the influence of human capital of inventors on the decision to keep or discard a patent. The results showed that having star inventors on the team of inventors, having more coinventors, and having inventors from multiple locations significantly raised the 


\section{Henry Anderson Junior and Jan Stejskal}

chances of renewal of patent. Additionally, having more coinventors positively moderates the effects of star inventors on patent renewal.

However, Pérez and Diaz (2010) in an empirical study assessed 157 firms in Canary Island and arrived at the conclusion that high commitment to an effective human resource management (HRM) had a positive influence on process innovation in firms. Their results also showed that the structural formalisation of firm's human resource policy and job stability also raised firms' level of patent generation (Seeck and Diehl 2016); however, regarding the role of human capital as a determinant of public and private expenditure, there hasn't been a clear-cut direction between the diversity or quality of human capital and public or private expenditure. It could be explained that the impact assessment has taken a different direction such that Knowledge as an asset is assumed to dwell in the firms' human capital and the output of these persons is what is generates firms' productivity, patents and competitive advantage. Most researches have rather focused on the quality of human capital affecting foreign direct investment (Agbola 2013; Thangavelu and Narjoko 2014; Kottaridi and Stengos 2010). Foreign-direct investment (FDI) inflows are considered to be more strongly and positively related to improvement in human development when FDI policy restricts foreign investors from entering some economic sectors and when it discriminates against foreign investors (Reiter and Steenma 2010). In addition, they also found that the relationship between FDI and improvement in human development is also more strongly positive when corruption is low. Nevertheless, thorough research has established the relevance of public and private funding on firm's innovation input which is largely embodied in human capital; the research will test the connection of human capital on private and public expenditure in determining intellectual capital. Having revealed this, we also hypothesise that "Human capital and innovation friendliness has a significant impact on the public and private expenditure invested"- $\mathrm{H} 2$.

\subsection{Public and private funding, cooperation and intellectual capital}

Extensive literature have affirmed the recurring essence of public and private funding schemes on creation and generation of intellectual capital and cooperation. Henry Junior and Odei (2018) researched on Slovak countries and found a positive significance of National and European Union funding on the cooperation levels of Czech Republic, Slovakia and Hungary even though the impact differed based on the type of funding. This could also explained by the result of Teirlinck and Spithoven (2012) who found that public funding provided by the EU framework programme did not exert an impact on the creation or facilitation of industry-science cooperation, neither with universities nor with public research centres. He explained that this could occur due to the fact that EU funding is oriented at firms that are already cooperating and does not favour the cooperation of start-ups. Venture capital levels are already in the red zone in the European Union compared with China, Canada and United States and this is not even helped by the low mergers and acquisitions rate and consequently poor foreign-direct investment levels (European Commission 2018). Having known these we finally hypothesise that "Public and private expenditures has a significant effect on the cooperation centric activities of countries"- $\mathrm{H} 3$. The objective of the research thereof is to show the catalytic effect of intellectual capital indicators on themselves in the creation of intellectual capital to enable expert positioning of available national resources in creation and generating of intellectual capital.

\section{Data and methodology}

The research is of exploratory nature and employs the purposive sampling technique in selecting the unit of analysis. As the research is of quantitative nature and largely revolves around the innovation status, we employed the data from European Innovation Survey (2018). The data consist of innovation activities of all the twenty-eight (28) European Union (EU) member states as of 2018 and carefully scores the framework conditions of member states, the investments injected, the innovation activities involved and their impacts. This survey collects data about the innovation status of all European Union member states and relatively ranks them based on their scores. Member states are ranked as innovation leaders, strong innovators, moderate innovators and modest innovators relative to their performance with the European Union average score. This provides the platform for an active comparison of member states with one another for healthy competition and effective benchmarking of performances. We chose to research on the European Union due their renewed ambition of the Union to propel their innovation efforts to move far ahead of nearest competitors evidenced by the implementation of the Horizon 2020 funding scheme and other multiple funding schemes enacted to propel the wheels of innovation. This was also chosen because of the efforts to catch up financially in terms of research and expenditure invested and venture capital invested. This research will reveal the collective effects of indicators on intellectual capital and how they could be harnessed to expedite innovation processes without 


\section{Henry Anderson Junior and Jan Stejskal}

extensive recourse to merely funding schemes. As the research hinged on the intellectual capital generation, we selected indicators from framework conditions, investments and linkages from the investment activities as shown in table 1 below.

Table 1: Variables selected for SEM analysis

\begin{tabular}{|c|c|c|c|c|}
\hline Variables & Abbreviation & Category & $\begin{array}{c}\text { Variable } \\
\text { type }\end{array}$ & Resources \\
\hline New doctorate graduates & NDG & $\begin{array}{l}\text { Human capital } \\
\text { and Innovation } \\
\text { friendliness }\end{array}$ & Input/Output & \multirow[t]{3}{*}{$\begin{array}{l}\text { Servage (2009), } \\
\text { EIS (2018) }\end{array}$} \\
\hline Population completed tertiary education & TERP & $\begin{array}{l}\text { Human capital } \\
\text { and Innovation } \\
\text { friendliness }\end{array}$ & Input/Output & \\
\hline Lifelong learning & LL & Human Capital & Input/Output & \\
\hline International scientific co-publications & SCICOP & $\begin{array}{c}\text { Attractiveness } \\
\text { of } \\
\text { Research } \\
\text { systems }\end{array}$ & Input & EIS (2018) \\
\hline Foreign doctorate students & FDS & $\begin{array}{l}\text { Attractiveness } \\
\text { of } \\
\text { Research } \\
\text { systems }\end{array}$ & Input & EIS (2018) \\
\hline Broadband penetration & BBPEN & $\begin{array}{c}\text { Human capital } \\
\text { and Innovation } \\
\text { friendliness }\end{array}$ & Input/Output & $\begin{array}{c}\text { Ghosh (2017), EIS } \\
(2018)\end{array}$ \\
\hline Opportunity-driven entrepreneurship & ODE & $\begin{array}{c}\text { Human capital } \\
\text { and Innovation } \\
\text { friendliness } \\
\end{array}$ & Input/Output & EIS (2018) \\
\hline R\&D expenditure in the public sector & PUEXP & $\begin{array}{l}\text { Public and } \\
\text { private } \\
\text { expenditure }\end{array}$ & Input/Output & $\begin{array}{l}\text { Henry Junior and } \\
\text { Odei (2018), EIS } \\
(2018)\end{array}$ \\
\hline Venture capital investments & $\mathrm{VCl}$ & $\begin{array}{c}\text { Public and } \\
\text { private } \\
\text { expenditure }\end{array}$ & Input/Output & $\begin{array}{l}\text { Botazzi and Da Rin } \\
\text { (2002) Colombo, } \\
\text { Adda and Pirelli } \\
\text { (2016), EIS (2018) }\end{array}$ \\
\hline R\&D expenditure in the business sector & PREXP & $\begin{array}{c}\text { Public and } \\
\text { private } \\
\text { expenditure }\end{array}$ & Input/Output & $\begin{array}{c}\text { Hashi and Stojcic } \\
\text { (2013) } \\
\text { Anderson and } \\
\text { Stejskal (2019) } \\
\text { EIS (2018) } \\
\end{array}$ \\
\hline Non-R\&D innovation expenditure & NIE & $\begin{array}{l}\text { Attractiveness } \\
\text { of } \\
\text { Research } \\
\text { systems }\end{array}$ & Input & $\begin{array}{c}\text { Anderson and } \\
\text { Stejska (2019), } \\
\text { EIS (2018) }\end{array}$ \\
\hline Enterprises providing ICT training & EICT & $\begin{array}{l}\text { Attractiveness } \\
\text { of } \\
\text { Research } \\
\text { systems }\end{array}$ & Input & EIS (2018) \\
\hline Innovative SMEs collaborating with others & SMECOLLAB & Cooperation & Input/Output & $\begin{array}{c}\text { Natario (2018), EIS } \\
(2018)\end{array}$ \\
\hline Public-private co-publications & PPCP & Cooperation & Input/Output & EIS (2018) \\
\hline Private co-funding of public R\&D expenditures & PRCOFUND & Cooperation & Input/Output & EIS (2018) \\
\hline PCT patent applications & PAT & $\begin{array}{l}\text { Intellectual } \\
\text { capital }\end{array}$ & Output & $\begin{array}{c}\text { Bontis (1996), } \\
\text { Crema, C } \\
\text { Verbano (2016) }\end{array}$ \\
\hline Trademark applications & TRDMK & $\begin{array}{l}\text { Intellectual } \\
\text { capital }\end{array}$ & Output & $\begin{array}{l}\text { Forte and Matonti } \\
\text { (2017), Abdullah } \\
\text { and Othman } \\
\text { (2019) } \\
\text { EIS (2018) }\end{array}$ \\
\hline
\end{tabular}


Henry Anderson Junior and Jan Stejskal

\begin{tabular}{|c|c|c|c|c|}
\hline Variables & Abbreviation & Category & $\begin{array}{c}\text { Variable } \\
\text { type }\end{array}$ & Resources \\
\hline Design applications & DESAPP & $\begin{array}{c}\text { Intellectual } \\
\text { capital }\end{array}$ & Output & $\begin{array}{c}\text { Forte and Matonti } \\
\text { (2017), EIS (2018) }\end{array}$ \\
\hline
\end{tabular}

Source: Authors' selection from EIS (2018)

In analysing the data, we employed the Structural Equation Model (SEM) analysis to compute the collective and interactive impact of sub variables of Research attractiveness, Human Capital and Innovation friendliness, Public and private expenditure and Cooperation on intellectual capital generation. This tool was used to develop a model to analyse, test and confirm the above-stated hypothesis in the literature. It was selected due to its assumption of free distribution, its analytical capability of revealing moderating and mediatory roles and its compound of analytical tools that enable analysis of multiple latent variables with sub variables (Kock \& Hadaya, 2018) as well as its capacity to generally compute models in a multiple regression context. In using this model, as shown in table 2 , reliability tests had to be constructed to verify the fitness and reliability of the model. Reliability tests for Cronbach's alpha, rho's A, composite reliability and average variance extracted (AVE) all satisfied the conditions set by Hair et al. (2012). Additionally, cross loadings computed also showed all variables mapped to the latent variables created was significant.

Table 2: Results of construct reliability and composite reliability tests.

\begin{tabular}{|c|c|c|c|c|}
\hline Construct reliability & $\begin{array}{c}\text { Cronbach's } \\
\text { Alpha }\end{array}$ & Rho_A & $\begin{array}{c}\text { Composite } \\
\text { Reliability } \\
\text { (CR) }\end{array}$ & $\begin{array}{c}\text { Average } \\
\text { Variance } \\
\text { Extracted } \\
\text { (AVE) }\end{array}$ \\
\hline $\begin{array}{c}\text { Attractiveness of } \\
\text { Research systems }\end{array}$ & 0.857 & 0.893 & 0.912 & 0.777 \\
\hline $\begin{array}{c}\text { Human Resources \& } \\
\text { Innovation friendliness }\end{array}$ & 0.805 & 0.879 & 0.868 & 0.579 \\
\hline Linkages & 0.720 & 0.863 & 0.838 & 0.643 \\
\hline $\begin{array}{c}\text { Public and } \\
\text { private funding }\end{array}$ & 0.650 & 0.821 & 0.816 & 0.625 \\
\hline Intellectual Capital & 0.670 & 0.664 & 0.819 & 0.602 \\
\hline
\end{tabular}

Source: Authors' own computation

We also conducted a test of the variance inflation factor $(V(F)$ to verify the multi-collinearity level of the data used. According to Hair et al. (2012), there is a low multi-collinearity level if the variance inflation score ranks below 5.0. According to the results in Table 3, there was no strong multi-collinearity issues found.

Table 3: Variance Inflation factor (VIF)

\begin{tabular}{|c|c|c|c|c|c|c|c|c|c|}
\hline Variable & NDG & TERP & LL & SCICOP & FDS & BBPEN & ODE & PUEXP & VCI \\
\hline Score & 1.465 & 1.179 & 4.584 & 2.671 & 2.092 & 1.590 & 3.670 & 3.099 & 1.064 \\
\hline Variable & PREXP & NIE & EICT & SMECOLLAB & PPCP & PRCOFUND & PAT & TRDMK & DESAPP \\
\hline Score & 2.990 & 1.337 & 2.543 & 2.005 & 1.937 & 1.170 & 1.147 & 1.912 & 2.108 \\
\hline
\end{tabular}

\section{Results and analysis}

Results of the analysis presented below shows the SEM results conducted to test the hypothesis created.

Table 4: Results of test of Hypothesis.

\begin{tabular}{|c|c|c|c|c|c|}
\hline Hypothesis & Significance & SD & F square & P Values & Status \\
\hline $\mathrm{H} 1$ & $\begin{array}{c}\text { Attractiveness of Research systems -> } \\
\text { Human Resources \&_Innovation friendliness }\end{array}$ & 0.07 & 1.358 & $\begin{array}{c}0.000 \\
* * *\end{array}$ & Accepted \\
\hline & Attractiveness of Research systems _> Intellectual capital & 0.31 & 0.479 & $\begin{array}{c}0.045 \\
* * *\end{array}$ & \\
\hline $\mathrm{H} 2$ & $\begin{array}{c}\text { Human Resources \&_Innovation friendliness -> } \\
\text { Public and private funding }\end{array}$ & 0.05 & 2.106 & $\begin{array}{c}0.000 \\
* * *\end{array}$ & Accepted \\
\hline & $\begin{array}{c}\text { Human Resources \&_Innovation friendliness -> } \\
\text { Intellectual capital_ }\end{array}$ & 0.30 & 0.002 & 0.879 & \\
\hline
\end{tabular}


Henry Anderson Junior and Jan Stejskal

\begin{tabular}{|c|c|c|c|c|c|}
\hline Hypothesis & Significance & SD & F square & P Values & Status \\
\hline & $\begin{array}{c}\text { Linkages -> } \\
\text { Intellectual capital__ }\end{array}$ & 0.32 & 0.432 & $\begin{array}{c}0.017 \\
* * * \\
\end{array}$ & \\
\hline \multirow[t]{2}{*}{$\mathrm{H} 3$} & $\begin{array}{c}\text { Public and private funding -> } \\
\text { Linkages }\end{array}$ & 0.03 & 3.223 & $\begin{array}{c}0.000 \\
* * *\end{array}$ & Accepted \\
\hline & $\begin{array}{c}\text { Public and private funding -> } \\
\text { Techno innovation }\end{array}$ & 0.42 & 0.336 & $\begin{array}{c}0.054 \\
*\end{array}$ & \\
\hline
\end{tabular}

Significance levels are appraised such that “***”- p value is less than 0.00 ; “*”- p value is less than 0.05 ; “* "when $p$ value is less than 0.05

A quick look at table above shows the latent variables created all have a significant impact on the creation of intellectual capital excluding the Human capital and Innovation friendliness. This is contrary to most research such that it is recognised that knowledge and information resides in individual and the sharing, interaction, . Regarding the actual hypothesis created, the results showed that attractiveness of research systems has a strong significance to Human resources and innovation friendliness. The f squared test also shows a very strong effect on the output variable. This implies that research structures created has a high tendency to attract and determine the quantity and quality of human resource personnel attracted to a region. With that being revealed, countries can conveniently invest in highly attractive research structures with the confidence of replication of efforts in quality human capital and subsequent acceptable environment for even further quality personnel. Positive image created works in attracting new residents, tourists, potential employees and actively raises the interest on the part of the media and consequently the goodwill of city as well (Kotler, Keller, Brady, Goodman, Hansen, 2009). This can also be said to enhance promotional activities and strengthen the bargaining hand of regional authorities. The research supports the finding of Insch (2011) and Raszkowski (2012) and effectively accepts $\mathrm{H} 1$.

Furthermore, Human resource and innovation friendliness was found to have strong significance to the public private and venture capital invested in member states in the European Union. It is worth noting that already the venture capital level in the European Union is the lowest compared to United States, Canada and China as well and public expenditure levels have sought to be raised with the inception of the Cohesion policy aiming for $3 \%$ of Gross Domestic Product of EU member states to be invested into research and development. However, these results reveal that the human capital and friendliness of a regions does determine the public funding efforts and even investors interest in investing in the block and degree of public or private or even venture capital funding. This could be reasonably be explained that the quality or diversity of personnel does impact the funds committed to research and development of provided to a member state or a region even though it does have a strong influence on the intellectual capital via cooperation, knowledge sharing and other interactions. It could also be implied that if the human capital and innovation friendliness of a region significantly determines funds invested basically for research purposes, and we currently have a low R\&D investment and relatively poor venture capital investment levels, this could be interpreted as a failing workforce loss of trust in the human capital potential of the Union, a poor human capital management by organisations (Noe, Hollenbeck, Gerhart and Wright 2017) or even a poor organisational culture (Gully, Phillips, Castellano, Han,\& Kim, 2013) that operates harnessing of the potential and talents of human capital. Headey and Hodge (2009) revealed that working age population could affect economic growth since population dominated by the old and children use most of their resources to cater for young and old which may depress economic growth as EU's working population has been decried to be "greying" as working population keeps reducing (European Commission 2018), this could be a reason as well. Nevertheless, this effectively accepts $\mathrm{H} 2$.

Lastly, the public and private and venture capital levels revealed a strong significance on the level of cooperation of firms, institutions and academic bodies even as they both had a significant influence on creating intellectual capital. This effectively confirms $\mathrm{H} 2$ and implies that expenditures from all sectors invested in the cooperation centred activities has a strong bearing on collaborative activities. This is imperative as innovation in contemporary times have been largely information-based and centres on the interactive capacities of human resources to share and exchange information. Hence, it is comprehensible that private and public bodies have thrown their financial weight around cooperation centric initiatives to creating regional competitive advantage. This effectively confirms H3 and affirms the research of Henry-Junior and Odei (2018), Acosta, Coronado and Romero (2015) and Maietta (2015). However, Prokop and Stejskal (2018) presented another side of cooperation 


\section{Henry Anderson Junior and Jan Stejskal}

revealing that firms prefer to cooperate on process innovation and innovation results are reaped in cooperation when firms engage with cooperation with too much partners.

\section{Conclusion}

The paper set out to reveal the interactive influence of intellectual capital indicators and the synergistic significance on intellectual capital creation. We focused on the European Union as a bloc and assessed the variables of research and innovation attractiveness, human capital and innovation friendliness, public and private research funding, cooperation and intellectual capital represented by patents, design application and trademarks. We conducted this multi-analysis using Structural Equation Model (SEM).

$\mathrm{H} 1$ which supposed that the attractiveness of research and innovation systems did determine the quality and quantity of human capital attracted to the region as well the friendliness of the region was accepted. This reveals that in as much as human capital is attracted by attractive package compensation, regions could, also invest in rich regional structures and education programs that improves the quality and value of human capital thereby rendering them more valuable to themselves, the region and the firms involved. As stated by Raszkowski (2012), this places the region in a brighter light in terms of global recognition and employee popularity. This could be resorted to rather than attempts to provide more financial packages that could easily be misappropriated and embezzled or even inefficiently used.

$\mathrm{H} 2$ was also accepted. This hypothesis also supposed that human capital and friendliness of innovation is a significant determinant of the funding appropriated for research and development as well as venture capital levels. However, even though this hypothesis was fulfilled, it could be inferred that human capital management and possibly organisation structures in the European Union were not efficient enough in harnessing the potential of current human capital. It could be connected to the ageing population according to the 2018 Ageing Report by the European Commission, poor organisational cultural structure and also poor strategic and supervisory management of human capital resources. It is recommended that firms actively engage in open practices that instils confidence, belief and trust in the intra-organisational connections and even other inter-organisational networking to facilitate knowledge sharing and confident exploration and utilisation of human resource potential. Healthy competitions and science workshops can also be organised and hinged more on friendly competitions and collaborative accomplishments.

Finally, H3 which presupposed that public and private funding including venture capitals had significant influence on linkages, representing SMEs openly collaborating with other SMEs, public and private and even academia interactions, was also accepted. This finding had the highest effect of significance amongst all the statistically significant hypotheses found and strongly entrenches the need for adequate financial structures. Most authors have revealed that cooperation efforts lie at the forefront of open innovation efforts both with firms and regions. Countries are therefore recommended to instigate policies that actively support cooperation-endowed sessions and correspondingly motivate the not-so open firms to engage in open innovation to move in line and engage in a meaningful information interchange for the mutual growth of firms and regions considered.

Limitation of this research was such that the data considered did not have selective figures for individual member state analysis hence we couldn't point out the member states experiencing the poorest connection of input indicators to output indicators combined. We further recommended that any further analysis is conducted on a panel level to assess decade changes in pattern of preferences for open innovation and changes in significance overtime.

\section{References}

Abdullah, N.N. and Othman, M.B., 2019. Examining The Effects Of Intellectual Capital On The Performance Of Malaysian Food And Beverage Small And Medium-Sized Enterprises. Technology (IJCIET), 10(2), pp.135-143.

Agbola, F.W., 2013. Does human capital constrain the impact of foreign direct investment and remittances on economic growth in Ghana?. Applied Economics, 45(19), pp.2853-2862.

Audretsch, D.B. and Feldman, M.P., 2004. Knowledge spillovers and the geography of innovation. In Handbook of regional and urban economics (Vol. 4, pp. 2713-2739). Elsevier.

Bontis, N., 1996. There's a price on your head: managing intellectual capital strategically. Business quarterly, 60, pp.40-78.

Bontis, N., 2004. National intellectual capital index: a United Nations initiative for the Arab region. Journal of intellectual capital, 5(1), pp.13-39. 


\section{Henry Anderson Junior and Jan Stejskal}

Bozeman, B., Lee, S., Gaughan, M. and Chompalov, I., 2003. The impact of research collaboration on scientific productivity. In Social Studies of Science.

Bukowitz, W.R. and Williams, R.L., 2000. The knowledge management fieldbook. Financial Times/Prentice Hall.

Cassiman, B. and Veugelers, R., 2002. R\&D cooperation and spillovers: some empirical evidence from Belgium. American Economic Review, 92(4), pp.1169-1184.

Chesbrough, H. and Bogers, M., 2014. Explicating open innovation: Clarifying an emerging paradigm for understanding innovation. New Frontiers in Open Innovation. Oxford: Oxford University Press, Forthcoming, pp.3-28.

Colombo, M.G., D'Adda, D. and Pirelli, L.H., 2016. The participation of new technology-based firms in EU-funded R\&D partnerships: The role of venture capital. Research Policy, 45(2), pp.361-375.

Combs, J., Liu, Y., Hall, A. and Ketchen, D., 2006. How much do high-performance work practices matter? A meta-analysis of their effects on organizational performance. Personnel psychology, 59(3), pp.501-528.

Crema, M. and Verbano, C., 2016. Managing Intellectual Capital in I talian Manufacturing SMEs. Creativity and Innovation Management, 25(3), pp.408-421.

Dahlander, L. and Gann, D.M., 2010. How open is innovation?. Research policy, 39(6), pp.699-709.

Delaney, J.T. and Huselid, M.A., 1996. The impact of human resource management practices on perceptions of organizational performance. Academy of Management journal, 39(4), pp.949-969.

Delery, J.E. and Doty, D.H., 1996. Modes of theorizing in strategic human resource management: Tests of universalistic, contingency, and configurational performance predictions. Academy of management Journal, 39(4), pp.802-835.

Forte, W., Tucker, J., Matonti, G. and Nicolo, G., 2017. Measuring the intellectual capital of Italian listed companies. Journal of Intellectual capital, 18(4), pp.710-732.

Greco, M., Grimaldi, M. and Cricelli, L., 2015. Open innovation actions and innovation performance: a literature review of European empirical evidence. European Journal of Innovation Management, 18(2), pp.150-171.

Gully, S.M., Phillips, J.M., Castellano, W.G., Han, K. and Kim, A., 2013. A mediated moderation model of recruiting socially and environmentally responsible job applicants. Personnel Psychology, 66(4), pp.935-973.

Hashi, I. and Stojčić, N., 2013. The impact of innovation activities on firm performance using a multi-stage model: Evidence from the Community Innovation Survey 4. Research Policy, 42(2), pp.353-366.

Haucap, J., Heimeshoff, U. and Lange, M.R., 2016. The impact of tariff diversity on broadband penetration-An empirical analysis. Telecommunications Policy, 40(8), pp.743-754.

Headey, D.D. and Hodge, A., 2009. The effect of population growth on economic growth: A meta-regression analysis of the macroeconomic literature. Population and Development Review, 35(2), pp.221-248.

Heiman, B.A. and Nickerson, J.A., 2004. Empirical evidence regarding the tension between knowledge sharing and knowledge expropriation in collaborations. Managerial and Decision Economics, 25(6-7), pp.401-420.

Henry Junior, A. and Odei, S.A., 2018. The Influence of Public Support on University-Industry-Government Collaboration: the Case of the Czech Republic, Slovakia, Hungary and Romania. STATISTIKA-STATISTICS AND ECONOMY JOURNAL, 98(4), pp.352-361.

Insch, A., 2011. Branding the city as an attractive place to live. In City Branding (pp. 8-14). Palgrave Macmillan, London.

Jiang, K., Lepak, D.P., Hu, J. and Baer, J.C., 2012. How does human resource management influence organizational outcomes? A meta-analytic investigation of mediating mechanisms. Academy of management Journal, 55(6), pp.1264-1294.

Jiménez-Jiménez, D. and Sanz-Valle, R., 2011. Innovation, organizational learning, and performance. Journal of business research, 64(4), pp.408-417.

Jiménez-Jiménez, D., \& Sanz-Valle, R. (2011). Innovation, organizational learning, and performance. Journal of business research, 64(4), 408-417.

Jurczak, J., 2008. Intellectual capital measurement methods. Economics and organization of enterprise, 1(1), pp.37-45.

Kotler, P., Keller, K.L., Brady, M., Goodman, M. and Hansen, T., 2009. Marketing Management-European Edition. Harlow, England: Pearson Prentice Hall Publishing, pp.467-468.

Kottaridi, C. and Stengos, T., 2010. Foreign direct investment, human capital and non-linearities in economic growth. Journal of Macroeconomics, 32(3), pp.858-871.

Kwiek, M., 2015. The unfading power of collegiality? University governance in Poland in a European comparative and quantitative perspective. International Journal of Educational Development, 43, pp.77-89.

Lee, S., Park, G., Yoon, B. and Park, J., 2010. Open innovation in SMEs-An intermediated network model. Research policy, 39(2), pp.290-300.

Liu, K., 2014. Human capital, social collaboration, and patent renewal within US pharmaceutical firms. Journal of management, 40(2), pp.616-636.

Lundvall, B.Å. ed., 2010. National systems of innovation: Toward a theory of innovation and interactive learning (Vol. 2). Anthem press.

Luthy, D.H., 1998, August. Intellectual capital and its measurement. In Proceedings of the Asian Pacific Interdisciplinary Research in Accounting Conference (APIRA), Osaka, Japan (pp. 16-17).

MacDuffie, J.P., 1995. Human resource bundles and manufacturing performance: Organizational logic and flexible production systems in the world auto industry. ILR Review, 48(2), pp.197-221.

Maietta, O.W., 2015. Determinants of university-firm R\&D collaboration and its impact on innovation: A perspective from a low-tech industry. Research Policy, 44(7), pp.1341-1359. 


\section{Henry Anderson Junior and Jan Stejskal}

Malhotra, Y., 2000. Knowledge management for e-business performance: advancing information strategy to "internet time". Information Strategy: The Executive's Journal, 16(4), pp.5-16.

Noe, R.A., Hollenbeck, J.R., Gerhart, B. and Wright, P.M., 2017. Human resource management: Gaining a competitive advantage. New York, NY: McGraw-Hill Education.

Pérez-Oliva Díaz, J.F. and Portal Miranda, J.A., 2010. Enfermedad renal crónica: estrategia nacional para enfrentar este importante problema de salud. Revista Habanera de Ciencias Médicas, 9(2), pp.140-142.

Rahman, H. and Ramos, I., 2013, July. Challenges in adopting open innovation strategies in SMEs: An exploratory study in Portugal. In Proceedings of the informing science and information technology education conference (pp. 431-448). Informing Science Institute.

Raszkowski, A., 2012. The Importance of City Image in Socio-Economic Development. Nierówności społeczne a wzrost gospodarczy. Rozwój zrównoważony i problemy obszarów wiejskich. Scientific Bulletin, 29.

Reiter, S.L. and Steensma, H.K., 2010. Human development and foreign direct investment in developing countries: the influence of FDI policy and corruption. World development, 38(12), pp.1678-1691.

Seeck, H. and Diehl, M.R., 2017. A literature review on HRM and innovation-taking stock and future directions. The International Journal of Human Resource Management, 28(6), pp.913-944.

Teirlinck, P. and Spithoven, A., 2012. Fostering industry-science cooperation through public funding: differences between universities and public research centres. The Journal of Technology Transfer, 37(5), pp.676-695.

Thangavelu, S.M. and Narjoko, D., 2014. Human capital, FTAs and foreign direct investment flows into ASEAN. Journal of Asian Economics, 35, pp.65-76.

West, J. and Bogers, M., 2014. Leveraging external sources of innovation: a review of research on open innovation. Journal of Product Innovation Management, 31(4), pp.814-831.

West, J., Salter, A., Vanhaverbeke, W. and Chesbrough, H., 2014. Open innovation: The next decade.

Zhou, Y., Hong, Y. and Liu, J., 2013. Internal commitment or external collaboration? The impact of human resource management systems on firm innovation and performance. Human Resource Management, 52(2), pp.263-288. 